\title{
MERDEKA BELAJAR MELALUI PENGGUNAAN MEDIA AUDIO VISUAL PADA PEMBELAJARAN MENULIS TEKS DESKRIPSI
}

\author{
Ariyana $^{* 1}$, Intan Sari Ramdhani ${ }^{2}$, Sumiyani ${ }^{3}$ \\ ${ }_{1,2,3}$ Universitas Muhammadiyah Tangerang \\ Jalan Perintis Kemerdekaan I Babakan No.33, Cikokol, Kec. Tangerang, \\ Kota Tangerang, Banten, Indonesia \\ Email: ariyana.mpd@gmail.com ${ }^{* 1}$, intan.sariramdhani@gmail.com ${ }^{2}$, \\ sumiyani.kinanti@gmail.com ${ }^{3}$
}

\begin{abstract}
Abstrak
Berpikir kritis dapat mengelola kecerdasan kognitif dan emosional peserta didik, berdasarkan hal tersebut merdeka belajar bagi pendidik dan peserta didik sangat dibutuhkan saat ini. Terutama dalam pembelajaran menulis teks deskripsi melalui media audio visual. Untuk itu, tujuan penelitian ini adalah mendeskripsikan penerapan merdeka belajar melalui penggunaan media audio visual pada pembelajaran menulis teks deskripsi. Metode penelitian yang digunakan adalah metode deskriptif kualitatif. Objek penelitian ini adalah teks deskripsi melalui media audio visual yang diajarkan pada jenjang SMP kelas VII. Untuk mengumpulkan data digunakan teknik dokumentasi dan observasi. Teknik analisis data dengan cara diseleksi, diinterprestasi, dan disimpulkan. Uji keabsahan data menggunakan member check dan validasi pakar pembelajaran bahasa Indonesia. Hasil penelitian menunjukan bahwa 1) media audio visual dapat membantu pendidik dan peserta didik dalam kegiatan pembelajaran menulis teks deskripsi dalam menerapkan kebijakan merdeka belajar, 2) media audio visual yang digunakan dalam pembelajaran menulis teks deskripsi berpengaruh dalam meningkatkan nilai pendidikan, mengajak peserta didik berpikir kritis, serta memberikan pengalaman yang bermakna, 3) media audio visual dapat mempermudah di dalam menuliskan teks deskripsi secara langsung melalui informasi yang didapat, dan 4) media audio visual tidak akan membosankan bagi peserta didik karena materi menulis teks deskripsi yang disampaikan sangat variatif.
\end{abstract}

Kata kunci: merdeka belajar, menulis teks deskripsi, media audio visual

\section{FREEDOM OF LEARNING THROUGH THE USE OF AUDIO-VISUAL MEDIA IN LEARNING TO WRITE DESCRIPTIVE TEXT}

\begin{abstract}
Critical thinking can manage the cognitive and emotional intelligence of students, based on this, free learning for educators and students is needed today. Especially in learning to write descriptive text through audio-visual media. Therefore, the purpose of this study is to describe the application of independent learning through the use of audio-visual media in learning to write descriptive texts. The research method used is descriptive qualitative method. The object of this research is descriptive text through audio-visual media which is taught at the seventh grade junior high school level. To collect data used documentation and observation techniques. Data analysis techniques were selected, interpreted, and concluded. Test the validity of the data using member checks and validation of Indonesian language learning experts. The results
\end{abstract}


showed that 1) audio-visual media can help educators and students in writing descriptive text learning activities in implementing the independent learning policy, 2) audio-visual media used in learning to write descriptive text has an effect on increasing educational values, inviting students to think critically. , as well as providing a meaningful experience, 3) audio-visual media can make it easier to write descriptive text directly through the information obtained, and 4) audio-visual media will not be boring for students because the material for writing descriptive text conveyed is very varied.

Keywords: freedom of learning, write description text, audio visual media

\section{A. Pendahuluan}

Pendidikan merupakan proses mengubah perilaku induvidu melalui bimbingan, pengajaran, serta pengalaman sepanjang hayat. Baik pendidikan formal maupun nonformal memerlukan usaha sadar untuk berubah (Mutakallim, 2018). Menurut Undang-Undang Republik Indonesia Nomor 20 Tahun 2003, pendidikan adalah usaha sadar dan terencana untuk mewujudkan suasana belajar dan proses pembelajaran agar peserta didik secara aktif mengembangkan potensi dirinya untuk memiliki kekuatan spiritual keagamaan, pengendalian diri, kepribadian, kecerdasan, akhlak mulia, serta keterampilan yang diperlukan dirinya, masyarakat, bangsa, dan negara.

Pendidikan dan pembelajaran satu kesatuan yang tidak akan terlepas satu sama lainnya. Pembelajaran pada dasarnya merupakan upaya untuk mengarahkan peserta didik ke dalam proses belajar sehingga merdeka belajar dapat memperoleh tujuan belajar sesuai dengan apa yang diharapkan. Merdeka belajar yang diusung Menteri Pendidikan dan Kebudayaan Nadiem Makarim adalah kebebasan berpikir (Sudaryanto dkk., 2020). Peserta didik perlu mengungkap atau mengekspresikan kemampuannya berpikir untuk memecahkan suatu masalah. Hal ini tentunya tetap memerlukan bimbingan guru.

Merdeka belajar menstimulus guru untuk menciptakan inovasi baru yang sangat potensial untuk kegiatan belajar mengajar. Sementara itu, untuk peserta didik, merdeka belajar berarti dapat berpikir secara kritis setelah diberikan stimulus oleh guru. Kebijakan merdeka belajar pun diserahkam kepada pihak sekolah untuk melaksanakannya sesuai dengan empat program yang sudah dicanangkan. Empat program kebijakan pendidikan nasional "merdeka belajar" 
yaitu (1) USBN diganti ujian (assement), (2) 2021 UN diganti, (3) RPP dipersingkat, (4) zonasi PPDB lebih flexsibel (Suwandi, 2020). Dari kebijakan tersebut sangat jelas bahwa pemerintah dalam hal ini tidak berperan dalam penentuan prestasi belajar siswa, melainkan pihak sekolah yang menilai hasil belajar siswa. Kebebasan merdeka belajar sangat dibutuhkan untuk penentuan berpikir kritis tidak hanya peserta didik, tetapi pihak sekolah dalam menentukan kebijakan di sekolah masing-masing.

Proses merdeka belajar yang sudah dilaksanakan di sebagian sekolah tentunya berdampak pada perkembangan pengajaran. Apalagi saat ini di seluruh dunia termasuk Indonesia mengalami perubahan kegiatan belajar mengajar disebabkan Covid-19. Untuk itu, diperlukan media sebagai sarana belajar peserta didik yang mampu mempengaruhi perkembangan kognitif. Media sangat dibutuhkan sebagai alat bantu dan sumber belajar. Menurut Djamarah \& Zain (2013), media sebagai alat bantu dalam proses belajar mengajar yang dapat dijadikan sebagai penyalur pesan guna mencapai tujuan pengajaran. Sedangkan media sebagai sumber belajar adalah segala sesuatu yang dapat dipergunakan sebagai tempat di mana bahan pengajaran terdapat atau asal untuk peserta didik belajar sehingga peserta didik memperoleh pengalaman yang memberikan dampak perubahan perilaku yang positif ke depannya (Noermanzah dkk., 2018).

Media belajar yang dibutuhkan saat ini di era kenormalan baru sangat berpengaruh untuk perkembangan intelektual peserta didik. Hal ini dikarenakan mereka sudah cukup lama belajar di rumah. Dengan kenormalan baru diharapkan ada perubahan secara signifikan dalam proses pembelajaran. Sebelum kenormalan baru sebenarnya guru dan peserta didik sudah mengubah pola belajar mengajar yang tadinya di kelas kini berubah di rumah masing-masing dengan menggunakan berbagai aplikasi seperti Zoom Cloud Meeting, WhatsApp, Google Classroom, dan lain sebagainya. Kenormalan baru saat ini mengubah pola mengajar guru dan pola belajar peserta didik. Berkaitan dengan hal tersebut Mata Pelajaran Bahasa Indonesia pun mengubah cara mengajar terutama pada 
pembelajaran menulis teks deskripsi pada peserta didik dengan menggunakan media audio visual.

Pembelajaran menulis teks deskripsi melalui media audio visual di era kenormalan baru pada siswa kelas VII akan sangat berpengaruh pada mental siswa yang tidak bisa berkomunikasi secara langsung dengan guru. Untuk itu, seorang guru harus aktif mencari hal-hal yang baru dan menyenangkan dalam proses belajar. Media audio visual dapat menumbuhkan sikap penuh perhatian, kreativitas, dan kemampuan kognitif maupun psikomotorik peserta didik untuk mengembangkan penalarannya dari apa yang dilihat dan didengar (Fithriyani, 2019). Misalnya dari hasil penelitian Nurfaedah (2019) dan Khulasoh (2019) media audio visual mampu meningkatkan kreativitas dan motivasi siswa dalam menuangkan idenya dalam menulis puisi. Selain itu, media audiovisual juga menurut hasil penelitian Sakila (2020), mampu meningkatkan kemampuan siswa dalam menulis teks prosedur. Hal ini menunjukkan bahwa media audio visual belum diterapkan dalam meningkatkan kemampuan menulis teks deskripsi terutama dalam menerapkan kebijakan merdeka belajar.

Menulis teks deskripsi merupakan teks apabila dikemas dengan baik mampu mengajak peserta didik untuk berpikir kritis secara audio atau visual bahkan audio visual. Media audio visual sangat dibutuhkan mengajar peserta didik kenormalan baru agar tidak ada rasa jenuh pada peserta didik. Pembelajaran konvensional cenderung membuat peserta didik jenuh salah satunya tidak menggunakan media pada saat kegiatan belajar mengajar. Di era kenormalan baru melalui daring peserta didik pun dapat belajar teks deskripsi melalui aplikasi Zoom Cloud Meeting dengan menggunakan media audio visual. Kondisi seperti ini dapat menciptakan pemahaman peserta didik mengenai suatu objek yang akan ditulis dengan menggambarkan dan melukiskan suatu hal dapat dilihat dan didengar secara bersamaan secara langsung sebagai esensi dari pengertian teks deskripsi (Amrolani dkk., 2014). Menulis teks deskripsi merupakan proses dalam menuangkan tulisan dalam bentuk teks yang menggambarkan suatu objek tertentu secara jelas dan terperinci sehingga pembaca seolah-olah merasakan 
apa yang dideskripsikan oleh penulis (Karto, 2019; Ariyana dkk., 2020). Harapannya dengan dilaksanakan penelitian tentang penerapan media audio visual dalam pembelajaran menulis teks deskripsi, peserta didik terbantu secara merdeka belajar dalam menuangkan gagasannya dalam bentuk tulisan teks deskripsi yang baik sesuai dengan ciri-ciri teks deskripsi yaitu 1) penggambaran yang disampaikan melibatkan panca indera; 2) menjelaskan ciri-ciri fisik suatu objek, seperti bentuk warna, ukuran, atau lainnya secara rinci; dan 3) pembaca dapat ikut mendengar, melihat, dan/atau merasakan objek yang sedang digambarkan oleh penulis (Febrianti \& Thahar, 2020).

\section{B. Metode Penelitian}

Metode penelitian yang digunakan yaitu metode deskriptif kualitatif. Tujuan penggunaan metode deskriptif kualitatif agar mampu mendeskripsikan dan memaknai mengenai merdeka belajar melalui penggunaan media audio visual pada pembelajaran menulis teks deskripsi. Teknik pengumpulan data dalam penelitian ini menggunakan teknik observasi, wawancara, pustaka, dan dokumentasi. Instrumen utama dalam penelitian ini yaitu peneliti yang dibantu dengan lembar observasi, pedoman wawancara, sumber referensi yang relevan, dan gawai.

Data dalam penelitian ini adalah proses pembelajaran menulis teks deskripsi dengan menggunakan media audio visual siswa kelas VII. Teknik analisis data dengan cara reduksi data, seleksi data, interpretasi data, dan menyimpulkan hasil penelitian. Kemudian, Uji keabsahan data dalam penelitian ini menggunakan member check dan validasi pakar pembelajaran bahasa Indonesia. Member check dengan cara peneliti berulang kali menginterpretasi makna sesuai data utama yang diperoleh dari hasil seleksi data yang dibantu dengan tabulasi data, sedangkan validasi pakar membantu dalam memberikan masukan atau saran terhadap pemaknaan yang dilakukan oleh peneliti. 


\section{Hasil Penelitian dan Pembahasan}

\section{Hasil Penelitian}

Dari hasil analisis data hasil observasi, wawancara, kajian pustaka, dan dokumentasi perencanaan pembelajaran, pelaksanaan pembelajaran, dan evaluasi pembelajaran pada pembelajaran menulis teks deskripsi menggunakan media audio visual menunjukkan siswa mampu menuangkan gagasan secara kreatif dan mandiri dengan lebih baik dalam bentuk teks deskripsi. Hal ini sesuai dengan kebijakan merdeka belajar yang memberikan kebebasan peserta didik secara mandiri, kreatif, dan inovatif dalam menuangkan gagasannya dalam hal ini gagasan dalam bentuk teks deskripsi (Suwandi, 2020). Gagasan yang muncul tersebut terbantu karena pemberian media audio visual kepada siswa.

Hasil penelitian ini secara lebih rinci sebagai berikut: 1) media audio visual dapat membantu pendidik dan peserta didik dalam kegiatan pembelajaran menulis teks deskripsi dalam menerapkan kebijakan merdeka belajar, 2) media audio visual yang digunakan dalam pembelajaran menulis teks deskripsi berpengaruh dalam meningkatkan nilai pendidikan, mengajak peserta didik berpikir kritis, serta memberikan pengalaman yang bermakna, 3) media audio visual dapat mempermudah di dalam menuliskan teks deskripsi secara langsung melalui informasi yang didapat, dan 4) media audio visual tidak akan membosankan bagi peserta didik karena materi menulis teks deskripsi yang disampaikan sangat variatif.

\section{Pembahasan}

a. Merdeka Belajar

Merdeka belajar merupakan kemerdekaan berpikir secara kritis yang wajib dimiliki oleh guru. Tanpa terjadi sebuah perubahan dan tindakan pada guru, tidak mungkin bisa terjadi pada diri peserta didik. Menumbuhkan kesadaran kognitif pada peserta didik menjadikan kekutan berpikir yang dapat menggali potensi dan bakat yang dimiliki. Salah satu wujud merdeka belajar dapat mengembangkan pola pikir peserta didik serta dapat menumbuhkan literasi yang lebih luas pada 
peserta didik (Suwandi, 2020). Pada dasarnya belajar adalah untuk mendapatkan pengetahuan dan wawasan yang lebih dalam lagi.

Merdeka belajar bukan saja dimiliki oleh peserta didik, tetapi merdeka belajar juga dimiliki guru. Salah satu contoh yaitu kebebasan dalam pembuatan persiapan bahan ajar. Hal ini terbukti dengan Rencana Pelaksanan Pembelajaran (RPP) yang hanya dua sampai dengan tiga lembar per pertemuan berbeda dengan tahun sebelumnya yang sangat banyak isi dari RPP tersebut untuk satu pertemuan. Guru dapat menciptakan rangsangan dalam mengajar sebagai proses kreatif belajar terutama di masa pandemic Covid 19 saat ini. Memerdekakan untuk belajar berbasis social budaya secara integral.

Menurut Suryani dkk. (2018) media pembelajaran segala sesuatu yang digunakan untuk menyalurkan pesan serta dapat merangsang pikiran, perasaan, perhatian, dan kemauan siswa sehingga dapat medorong terjadinya proses belajar yang disengaja, bertujuan, dan terkenadali. Dengan demikian, media pembelajaran merupakan suatu pesan atau sarana untuk menyampaikan informasi ke pendengar agar peserta didik mampu memperoleh pengetahuan. Merdeka belajar dalam pelaksanaan kegiatan belajar mengajar sangat bermanfaat bagi pendidik, karena dapat menggunakan berbgai macam ragam media yang disesuaikan dengan materi ajar yang diajarkan. Kesesuain materi ajar dengan media terutama media audio visual sangat mampu menggambarkan objek yang ditampilkan dari media audio visual tersebut, peserta didik mampu mendeskripsikan objek berdasarkan urutan waktu, tempat dan suasana yang dirasakan dalam bentuk teks deskriptif. Hal tersebutlah yang ingin peneliti ungkap bahwa dengan merdeka belajar mampu menciptakan suasana belajar yang gembira, menyenagkan, dan berbobot.

\section{b. Kriteria Pemilihan Media}

Penggunaan media pembelajaran sebagai upaya untuk menumbuhkan ide dan gagasan peserta didik untuk megekspresikan apa yang dilihat dan didengar 
melalui media secara langsung maupun tak langsung (Hudhana \& Sulaeman, 2019). Assosiation of Education and Communcation Technology (AECT) menyatakan bahwa media segala bentuk upaya untuk penyampaian informasi. Sementara itu, Asosisasi Pendidikan Nsional (National Education Assosiasian/NEA) menyatakan media sebagai bentuk-bentuk komunikasi baik tercetak, noncetak, audio, visual, dan audio visual (Angkowo \& Kosasih, 2007). Media pembelajaran yang digunakan guru dalam proses belajar mengajar sebaiknya disesuaikan dengan materi ajar yang akan disampaikan. Dalam hal ini guru bahasa Indonesia, sudah menyesuaikan materi teks deskriptif ke dalam media audio visualnya. Media mempunyai arti yang sangat penting karena dalam kegiatan belajar mengajar sebagai perantara untuk menyampaikan informasi.

Pemilihan media dapat memberikan kesamaan pengalaman kepada peserta didik tentang hal-hal yang dipelajarinya secara nyata dan jelas, serta memungkinkan terjadinya interaksi langsung dengan pendidik, secara langsung melalui Pembelajaran Jarak Jauh (PJJ). Pemilihan media sangat penting ketika seorang guru akan mengajar, hal ini akan berdampak pada proses belajar dan hasil belajar. Pendidik yang inovatif di era kenormalan baru sangat diharapkan dapat mengkolobarasikan antar materi dan media. Dalam penelitian ini guru sudah memilih media sesuai dengan pendapat Arifin \& Setiyawan (2012), sebagai berikut.

1. Kompetensi dasar dan indikator apa yang akan dicapai dalam suatu kegiatan pembelajaran.

2. Materi pembelajaran (instructional content), yaitu bahan atau kajian apa yang akan diajarkan pada program pembelajaran tersebut.

3. Keakraban media dan karakteristik siswa dan guru yaitu mengkaji sifat dan ciri media yang akan digunakan.

4. Adanya sejumlah media yang bisa dibandingkan karena pemilihan media pada dasarnya adalah proses pengambilan.

Pemilihan media perlu memperhatikan manfaat yang akan diperoleh peserta didik setelah kegiatan belajar mengajar agar proses belajar akan 
mendapatkan hasil yang baik. Selain itu, pemilihan media juga perlu memperhatikan hal-hal seperti berikut: (1) kesiapan guru dan peserta didik, (2) sarana dan prasarana yang mendukung, dan (3) media relevan dengan materi ajar yang akan diajarkan. Untuk pemilihan media menjadi skala prioritas dalam kegiatan belajar mengajar.

Kenormalan baru tentunya mengubah paradigma kegiatan belajar mengajar di kelas, tetapi dengan konsep merdeka belajar di era pandemi ini mewajibkan pendidik untuk berinovatif menciptakan pembelajaran yang menyenangkan. Membuat sebuah pembelajaran menjadi terkesan variatif dan tidak terkesan komunikasi verbal saja, sehingga peserta didik menjadi tertarik dan tidak mudah bosan. Sebuah media pendidikan atau pembelajaran harus memiliki fungsi motivasi pada pembelajaran peserta didik yang mampu mengubah peserta didik untuk tertarik terhadap materi yang diajarkan oleh pendidik.

Media yang dibutuhkan peserta didik saat ini adalah media yang dapat memberikan gambaran yang jelas untuk melukiskan suatu keadaan, yang nantinya media tersebut dapat menjadi inspirasi peserta didik untuk mengembangkan ide dan gagasan. Media pendidikan merupakan sebuah alat atau komponen dalam sebuah materi pengajaran yang dapat berupa gambar atau alat yang mampu menangkap proses atau kejadian yang memudahkan peserta didik untuk memahami sebuah materi yang diajarkan. Sebuah media pendidikan dapat dikatakan berhasil apabila media tersebut mampu menghantarkan materi kepada peserta didik dengan baik dan memotivasi dalam belajar. Berikut ini adalah salah satu contoh media yang akan dibahas adalah media audio visual.

Media yang dipilih haruslah obkektif didasari dengan kebermanfaatan dan keberhasilah agar tujuan belajar tercapai. Pemilihan media tentunya sangat mendukung pada interkasi pendidik dan peserta didik, tidak hanya di dalam kelas, bahkan saat ini pembelajaran daring pun dapat menciptakan suasana belajar yang efektif, apabila media yang digunakan tepat untuk kompetensi yang diajarkan. 


\section{c. Media Audio Visual}

Media audio visual sangat bermanfaat untuk peserta didik kelas VII pada pembelajaran menulis teks deskripsi. Dengan melihat dan mendengar secara langsung dapat menulis teks sesuai konteks yang ditampilkan. Menurut Arsyad (2017) media audio visual adalah media yang menggabungkan penggunaan suara dan menggabarkan atau menulis materi pelajaran (h.91). Penggabungan unsur mendengar menulis dan melihat dalam satu rangkaian pembelajaran akan dengan mudah memberikan pemahaman pada peserta didik. Sedangkan Sanjaya (2010) media audio visual adalah media yang mempunyai unsur suara dan unsur gambar yang bisa dilihat misalnya rekaman, video, side, suara dan sebagainya (h. 172). Dengan menggunakan media visual, materi yang sekiranya membutuhkan penggambaran secara langsung akan lebih terealisasikan kepada peserta didik. Jadi, peserta didik akan mendapatkan penggambaran nyata dari penggunaan media visual ini. Menurut Suryani, dkk (2018) kelebihan media audio visual sebagai berkut.

1) Lebih efektif dalam menerima pembelajaran karena dapat melayani, baik gaya bahasa siswa yang auditif maupun yang visual.

2) Dapat memberikan pengalaman nyata lebih dari yang disampaikan media audio maupun visual.

3) Siswa akan lebih cepat mengerti karena mendengar disertai melihat langsung.

4) Lebih menarik dan menyenangkan menggunakan media audio visual.

Jadi, media audio visual sangat memudahkan bagi peserta didik sehingga dapat berimajinasi atau membayangkan tampilan dari materi yang diberikan guru. Selain kelebihan tentunya terdapat juga kekurangan dari media audio visual sebagai berikut.

1) Pembuatan media audio visual memerlukan waktu yang lama, karena memadukan dua eleman, yakni audio dan visual.

2) Membutuhkan keterampilan dan ketelitianya dalam pembuatanya.

3) Biaya yang digunakan dalam pembuatan cukup mahal. 
4) Jika tidak terdapat peranti akan sulit untuk membuatnya.

Dengan demikian, sebagai pendidik harus lebih meminalisir kekurangan suatu media sehingga dapat diantisipasi menjadi lebih bermanfaat dan tepat guna. Setiap produk media tidak ada yang sempurna tetapi seorang guru mampu menciptakan suasana belajar yang kondusif dan menyenangkan.

Dari hasil penelitian ini, penggunaan media audio visual juga dapat mempertinggi perhatian anak dengan tampilan yang menarik. Selain itu, anak akan takut ketinggalan jalannya video tersebut jika melewatkan dengan dengan mengalihkan konsenterasi dan perhatian. Media audio visual yang menampilkan realitas materi dapat memberikan pengalaman nyata pada siswa saat mempelajarinya sehingga mendorong adanya aktivitas diri.

Media audio visual sangat membantu bagi peserta didik dengan merdeka belajar di masa pandemi, karena peserta didik dapat belajar dari rumah atau lebih dikenal saat ini Pendidikan Jarak Jauh (PJJ). Kecanggihan tekologi dapat memudahkan siapapun dalam belajar tidak terbatas ruang dan waktu. Media audio visual sangat berfungsi untuk perkembangan kognitif dan psikomotorik peserta didik. Hal ini seperti yang diungkap oleh Wati (2016) mengenai fungsi media audio visual, antara lain: (1) lebih efektif dalam pembelajaran, (2) berfungsi sebagai integral dari keseluruhan proses pembelajaran, (3) sebagai hiburan, (4) mempercepat proses pembelajaran, dan (5) meningkatkan kualitas pembelajaran.

Dengan demikian, media audia visual sangat tepat digunakan dalam proses pembelajaran menulis teks deskripsi, salah satunya dapat menghibur peserta didik. Penggunaan dua unsur indera pada media audio visual yakni unsur gambar dan suara mampu mengambangkan pemahaman peserta didik dalam mempelajari teks deskripsi. Penggunaan media berbasis audio visual ini dapat menarik minat siswa dalam mempelajari teks deskripsi. Pemahaman mengenai sebuah informasi atau materi yang disampaikan melalui media audio visual akan membuka pikiran peserta didik dan memberikan kesan hidup dalam pembelajaran menulis teks deskripsi. 


\section{d. Pembelajaran Teks Deskripsi Menggunakan Media Audio Visual}

Peserta didik kelas VII SMP setelah diberikan media audio visual pada pembelajaran menulis teks deskripsi menjadi lebih kreatif dan mandiri dalam menuangkan idenya ke dalam bentuk tulisan deskripsi. Hal ini dibuktikan dengan hasil observasi peserta didik sebagian besar antusias dan semangat dalam belajar dengan penyajian media audio visual dalam bentuk video pembelajaran. Selain itu, dari hasil kegiatan menulis teks deskripsi siswa sudah mampu menulis teks deskripsi sesuai dengan ciri-ciri teks deskripsi, yaitu 1) penggambaran yang disampaikan melibatkan panca indera; 2) menjelaskan ciri-ciri fisik suatu objek, seperti bentuk warna, ukuran, atau lainnya secara rinci; dan 3) pembaca dapat ikut mendengar, melihat, dan/atau merasakan objek yang sedang digambarkan oleh penulis (Febrianti \& Thahar, 2020). Hasil kemampuan siswa dalam menulis teks deskripsi juga sudah $80 \%$ di atas nilai kriteria ketuntasan minimal.

Media audio visual ini bisa diterapkan dengan baik karena guru menjalankan kebijakan merdeka belajar secara maksimal dengan memberikan kebebasan kepada siswa dalam mengekspresikan diri secara kreatif dan inovatif dalam menuangkan idenya melalui bantuan video pembelajaran (Suwandi, 2020). Dalam hal ini, guru memiliki peran sentral dalam mengantarkan siswa terutama dalam menghadapi era 5.0 yang menuntut siswa menguasai kemampuan komunikasi dan kolaborasi; kemampuan berpikir kritis, kreatif, dan inovatif; kemampuan untuk cepat beradaptasi dengan perubahan-perubahan; fleksibilitas pribadi; kemampuan untuk belajar dan mengaplikasikan keterampilan baru, serta komputasi dan mengolah data besar (Kusmiarti, 2020).

\section{Simpulan}

Hasil penelitian menunjukan bahwa: 1) media audio visual dapat membantu pendidik dan peserta didik dalam kegiatan pembelajaran menulis teks deskripsi dalam menerapkan kebijakan merdeka belajar, 2) media audio visual yang digunakan dalam pembelajaran menulis teks deskripsi berpengaruh dalam meningkatkan nilai pendidikan, mengajak peserta didik berpikir kritis, serta 
memberikan pengalaman yang bermakna, 3) media audio visual dapat mempermudah di dalam menuliskan teks deskripsi secara langsung melalui informasi yang didapat, dan 4) media audio visual tidak akan membosankan bagi peserta didik karena materi menulis teks deskripsi yang disampaikan sangat variatif.

Di era kenormalan baru merdeka belajar perlu bersinergi antara orangtua, guru dan pihak sekolah hal ini diperlukan untuk perkembangan psikologi dan sosial emosi peserta didik. Media audio visual sangat baik digunakan untuk materi menulis teks deskripsi pada Mata Pelajaran Bahasa Indonesia jenjang SMP kelas VII.

Penulis berharap dengan penelitian merdeka belajar pada pembelajaran menulis teks deskripsi melalui audio visual dapat dijadikan solusi maupun sebagai media pembelajaran alternatif bagi pendidik. Selain itu, penulis berharap akan ada lagi penelitian lanjutan yang akan dijadikan media pembelajaran bagi pendidik dan peserta didik dalam mencapai tujuan pembelajaran lebih maksimal.

\section{Daftar Pustaka}

Amrolani, A., Muslihah, N. N., \& Noermanzah, N. (2014). Peningkatan Kemampuan Menulis Karangan Deskripsi melalui Teknik Imajinasi Siswa Kelas IV SD Negeri 51 Lubuklinggau. Jurnal Perspektif Pendidikan, 8(1), $1-2$.

Angkowo, R. \& Kosasih, A. (2007). Optimalisasi Media Pembelajaran. Jakarta: Grasindo.

Arifin, Z. \& Setiyawan, A. (2012). Pengembangan Pembelajaran Aktif dengan ICT. Yogyakarta: Skripta Media.

Ariyana, A., Enawar, E., Ramdhani, I. S., \& Sulaeman, A. (2020). The Application of Discovery Learning Models in Learning to Write Descriptive Texts. Journal of English Education and Teaching, 4(3), 401-412. doi:10.33369/jeet.4.3.401-412.

Arsyad, A. (2017). Media Pembelajaran. Jakarta: Raja Grafindo. 
Djamarah, S. B. \& Zain, A. (2013). Strategi Belajar Mengajar. Jakarta: Rineka Cipta.

Febrianti, V., \& Thahar, H. E. (2020). Komparasi Keterampilan Menulis Teks Deskripsi dengan Keterampilan Menulis Teks Cerita Fantasi Siswa Kelas VII SMP Negeri 7 Padang. Pendidikan Bahasa Indonesia, 9(2), 72. doi:10.24036/108993-019883

Fithriyani, I. (2019). Peningkatan Perhatian, Aktivitas, dan Keterampilan Menulis Cerpen melalui Model Pembelajaran Berbasis Masalah dan Media Audio Visual. Lingua Rima: Jurnal Pendidikan Bahasa dan Sastra Indonesia, 8(2), 11. doi:10.31000/lgrm.v8i2.1783

Hudhana, W. D. \& Sulaeman, A. (2019). Pengembangan Media Video Scribe dalam Peningkatan Kemampuan Menulis Cerpen Berbasis Karakter Siswa Kelas X SMA se-Kabupaten Tangerang. Pena : Jurnal Pendidikan Bahasa dan Sastra, 9(1), 32. doi:10.22437/pena.v9i1.6839

Karto, Suhartono, Susetyo, Noermanzah, Maisarah, I. (2019). The Differences Ability in Writing Descriptive Texts by Using Chain Writing and Conventional Methods. International Journal of Scientific \& Technology Research, 8(10), 2718.

Khulasoh, K. (2019). Meningkatkan Keterampilan Menulis Puisi Menggunakan Media Audio Visual Pokok Bahasan Melengkapi Puisi Anak Berdasarkan Gambar Model Pembelajaran Tematik. Dinamika Jurnal IImiah Pendidikan Dasar, 9(1). doi:10.30595/dinamika.v9i1.3855

Kusmiarti, R., Yuniati, I., \& Noermanzah. (2020). Improving Student Communication Skills In Learning Indonesian Language Through Collaborative Learning. Retrieved from osf.io/9km3u. International Journal of Scientific and Technology Research, 9(1).

Mutakallim. (2018). Pendidikan Pluralisme melalui Kurikulum Pendidikan Agama Islam Berbasis Kemajemukan. Inspiratif Pendidikan, 7(2), 307. doi:10.24252/ip.v7i2.7914

Noermanzah, N., Abid, S., \& Septaria, S. (2018). Improving the Ability of Writing a Narrative Charge by Using Animated Images Media Student Class V.B SD Negeri 17 Lubuklinggau. BAHTERA : Jurnal Pendidikan Bahasa dan Sastra, 17(2), 116. doi:10.21009/bahtera.172.9

Nurfaedah, N. (2019). Keefektifan Media Audio Visual dalam Meningkatkan Kompetensi Siswa Sekolah Menengah Pertama dalam Menulis Puisi. 
Indonesian Journal of Instructional Media and Model, 1(1). doi:10.32585/ijimm.v1i1.316

Sakila, S. (2020). Meningkatkan Hasil Belajar Siswa pada Pembelajaran Menulis Teks Prosedur dengan Media Audio Visual. Genta Bahtera: Jurnal IImiah Kebahasaan dan Kesastraan, 6(1), 60-89. doi:10.47269/gb.v6i1.98

Sudaryanto, S., Widayati, W., \& Amalia, R. (2020). Konsep Merdeka BelajarKampus Merdeka dan Aplikasinya dalam Pendidikan Bahasa (dan Sastra) Indonesia. Kode: Jurnal Bahasa, 9(2). doi:10.24114/kjb.v9i2.18379

Suryani, N., Setiawan, A., \& Putria, A. (2018). Media Pembelajaran Inovatif dan Pengembangannya. Bandung: Remaja Rosdakarya.

Suwandi, S. (2020). Pengembangan Kurikulum Program Studi Pendidikan Bahasa (dan Sastra) Indonesia yang Responsif terhadap Kebijakan Merdeka Belajar-Kampus Merdeka dan Kebutuhan Pembelajaran Abad ke-21. Prosiding Seminar Nasional Pendidikan Bahasa dan Sastra, Universitas Bengkulu, https://ejournal.unib.ac.id/index.php/semiba/article/view/13356

Undang-Undang Republik Indonesia Nomor 20 Tahun 2003 tentang Sistem Pendidikan Nasional.

Wati, E. R. (2016). Ragam Media Pembelajaran. Jakarta: Kata Pena. 